\title{
Nasìm-e țarab. Tehrān, Farhangestān-e Honar, 1385/2006, 128 p (persan) + 25 p. (anglais), index.
}

\section{Sāsān Fāṭemī}

\section{(2) OpenEdition}

1 Journals

\section{Édition électronique}

URL : http://journals.openedition.org/abstractairanica/33782

DOI : 10.4000/abstractairanica.33782

ISSN : 1961-960X

Éditeur:

CNRS (UMR 7528 Mondes iraniens et indiens), Éditions de l'IFRI

\section{Édition imprimée}

Date de publication : 15 mai 2008

ISSN : 0240-8910

\section{Référence électronique}

Sāsān Fāțemī, « Nasīm-e țarab. Tehrān, Farhangestān-e Honar, 1385/2006, 128 p (persan) + 25 p. (anglais), index. », Abstracta Iranica [En ligne], Volume 29 | 2008, document 442, mis en ligne le 15 septembre 2008, consulté le 26 septembre 2020. URL : http://journals.openedition.org/ abstractairanica/33782 ; DOI : https://doi.org/10.4000/abstractairanica.33782

Ce document a été généré automatiquement le 26 septembre 2020.

Tous droits réservés 


\section{Nasìm-e tarab. Tehrān, Farhangestān-e Honar, 1385/2006, $128 \mathrm{p}$ (persan) $+25 \mathrm{p}$. (anglais), index.}

\section{Sāsān Fāțemī}

1 Ancien traité de musique qui date probablement de l'époque safavide. Selon l'éditeur, il a été écrit au $\mathrm{X}^{\mathrm{e}} / \mathrm{XVI}^{\mathrm{e}} \mathrm{s}$., par un auteur inconnu du nom de Nasīmī, qui l'a dédié à Amīre-ye Dobāj, gouverneur du moment de la région de Gīlān. C'est la publication du seul manuscrit existant de ce traité, daté du XII ${ }^{\mathrm{e}} / \mathrm{XVIII}^{\mathrm{e}}$ s., qui est conservé à la bibliothèque de majles-e šowrā-ye eslāmī sous le numéro 39537. Comme le précise l'éditeur, ce traité versifié a certaines particularités qui le distinguent des autres traités de l'époque, surtout dans les vingt chapitres concernant le rythme (le traité comporte au total 39 chapitres) où l'A. présente certains cycles rythmiques qui ne sont pas mentionnés par d'autres sources.

\section{INDEX}

Thèmes : 17.1.Musique 
AUTEURS

SĀSĀN FĀṬEMĪ

Université de Téhéran 